\title{
Library Services in ICT Environment
}

\author{
Jayant Deshpande
}

Librarian, Indian Institute of Carpet Technology, Chauri Road, Bhadohi, UP, India

\begin{abstract}
The study presents the needs of library services in information and communication environment for the libraries and the information centers. The Information and Communication Technology (ICT) has transferred the library services all around the world, now days most of the information recorded in electronic format. ICT is playing a vital role to improve the performance of libraries. \& digitization of the libraries facilitates easy \& immediate access to information. A library service in ICT environment has availed the libraries to keep pace with the latest development. This has additionally facilitated precision, flexibility and reliability in the library and information centre. Library services reduce the perpetual work and preserve them and brings precision and speed \& keeps material safe.
\end{abstract}

Keywords - Resource sharing, library networking, user awareness, electronic library, library management.

\section{WHY IT APPLICATIONS}

Libraries are moving rapidly towards the electronic method of storage and retrieval. In the recent years, Internet has been the major force, which has led to the electronic versions of library amassments. Due to following reasons IT application plays a vital role. Following are the reasons for why IT applications need in today's scenario:

- Increase in Resource sharing:

Due to revolution of information it is difficult to acquire all the materials needed by the clientele. In fact partnership and cooperation in local, national and international have become enviable for all libraries. In achieving cooperation is through the establishment of consortium.

\section{- Importance of library networking}

Presently all Govt. public libraries working under Directorate of Libraries are having more or less same collection of copyright books. These books are old and rare which are not easily available elsewhere and difficult to find if needed. Also data of books available in all libraries is not available at one point. Communication between libraries is also very rare. Hence, chances of duplication of books are more. Due to these barriers, libraries are lacking in giving services to its readers.

- Transformation of printed materials

- Digitized information

Digital information is a type of information stored using a series of ones and zeros, according to TechTerms.com. It is the most commonly used method of storing and reading data, as it can be copied, edited and moved without losing any quality.

\section{- User awareness}

As information systems become increasingly distributed (through mobile computing, desktop computing, etc), users is increasingly placed in a position where they must handle information security matters that they did not handle in days gone past. These new distributed systems force users to play security roles that they had not previously had to play.

- The electronic library

Physical site and/or website that provide 24-hour online access to digitized audio, video, and written material.

\section{FUNCTIONS OF LIBRARY MANAGEMENT SYSTEM}

Manage Book and Member Record

- Easily manage Member and book detail with the help of Barcode.

\section{Acquisitions}

- With library Management software, Acquisitions function as generate Purchase order, Cancel Purchase Order, Reminder Purchase order, Receive Purchase Order, Invoice and instantly available in the Reports . Data can be search by feeding Purchase Order no, Invoice No, Supplier name .

\section{Circulation}

- Library Management Software enables the complete management of multiple Item issues and return of books using Manual or Barcode Scanner.

\section{Barcode}

- Use of Bar Codes for Library Management eases the everyday tasks of big Libraries, where the No. of 
transactions exceeds several thousands in number. Moreover, the software can work even without Bar Codes seamlessly. The Bar-Code generation and printing process is a Built-In feature of this Software.

OPAC

- Library management software admin/Member can easily search book author, Title, Accession No, Publication, and Language also admin can filter data by category wise.

Facility for User to Suggest items

- User suggestion and request for purchasing a new item is handled by the software itself reducing the administrator's task.

\section{Alert through Email}

- Admin can send mail to members, vendors, or any other people from the software.

\section{Multiple Library Setup}

- Library management software can setup at different locations.

\section{Export All Report into Excel, Word}

- Admin can take all the details which are displayed in the reports into excel and word file.

Handles donated items, free items and keep track of donors

- Some library items are free or some person donates the item. So Library management software keeps track of those items.

\section{Provide Multi User environment}

- Library management software gives facility of multi user environment. Multiple users can login at the same time in the Library management software.

\section{Maintain Any Media}

- You can define a number of things that one wants to keep track of.

- One can maintain different kinds of media like Book, CD, File Documents, Video Cassette, and Audio Cassette.

- One can maintain media with its own specifications rather than common.

- You define the specification you want for that media, for book (pages, ISDN number, type, volume).

\section{Powerful Search Engine}

- Library Software includes searches for words, phrases and more within single sentences in a book, or your entire library.

- $\quad$ Includes (+," ",-) operators.

- $\quad$ 'Powerful reference searching' you can find resources about any given media anywhere in your library.
- $\quad$ Find media by any keyword typed in text box or by selecting the name of media author, publisher or subject also find different combinations of author, publisher, subject and sub subject.

- Define search field and select particular fields to display the result.

\section{Custom Field Indices}

- Library Software provides sorted data on required fields by clicking on the column header. i.e. if clicked on publisher the data will be sorted on publisher.

- One each master form.

\section{Lock System}

- Lock the subject or group of the member, so that media can't be issued which falls under these criteria. One can in this way restrict the issuing of the media.

\section{Circulation}

- Easy operation of circulation by entering the code of media, get all the information related to the media and the number. (name, group, media type)

\section{Easy Navigation and Updating}

- Selecting an option from the given menu provides all the data related to that option in tabular format in a user friendly manner.

\section{Auto Filter \& Auto Search}

- On each master form, Library Software will search on the field where your cursor is and what you type is taken as a search value.

\section{Customize}

- User can customize the system to feel easier for data entry.

- While adding records user can keep form in 'add' mode. Define Holidays.

- Set the criteria of issuing the book if member is requested for media or not.

Scrap-Type

- Define their own scrap type for scraping the media. Provides scrap runner utility to record the number of scrap media.

\section{Reports}

- Member wise report.

- Media wise report.

- Time duration and media name for which user want the report.

- $\quad$ More specific report.

\section{$>$ Creating a Technology Plan}

Our technology plan supports the mission of the library to: Provide accessible and innovative services in response 
to community needs, while helping to accomplish its vision of: High-speed internet service, new technology and education to integrate technology into daily life.

- Identification of basic functions of the library

The basic functions of any library are: ordering and acquisitions, cataloguing, circulation control, serials control, management information and community information control. A library manager must always look for ways in which these functions can be integrated in order to reduce duplication of effort. Much of the software available in the market provides this integration in the sense that the software is provided in a series of modules covering specific functions which together form a complete system from acquisitions to online catalogue. 'Modules can be bought as required and or as funding permits. Each module will work with all others, allowing records to he transferred from one to the other. The main objective is to indicate the factors which must be taken into consideration while studying automation of routines and to examine how some of the software performs with this type of activity.

\section{- Planning for library automation}

Planning for an automated system, no matter how big or small, should be part of an overall long-range plan for the library. Automation should always be used as a means to achieve overall better patron service. Careful planning for technology will assure that your automation project is "sustainable", i.e. enhances the organization's ability to meet its service mission without disrupting the organizational stability of the institution.

\section{- Identify key issues influencing the library}

- Define the ultimate outcomes

- Assessment of existing technology and services, user needs

- Establish priority

- Develop missions, goals and objectives

- Financial and implementation considerations

\section{CONCLUSION}

The digital library movement in India is rapidly increasing and the traditional libraries are now on their way to digitization with the prelude of ICT application in the library sector, data of all libraries will be handled with facileness, precision, great speed, high rate and more preponderant quality. It will preserve cost, time and labour of library staff and will avoid duplication of work. All libraries will be connected through networking, hence amassment will be shared. It will additionally avail to adopt the felicitous strategies for ameliorating accumulation building. Union catalogue and cooperative bibliographic accommodations will be introduced. However ICT application/automation and networking is must require for any kind of libraries \& information center.

\section{REFERENCES}

[1] Blair, Gerard M. "Presentation Skills." Basic Management Skills. University of Edinburgh, School of Engineering. Web. 06 May 2009. $<$ http://www.see.ed.ac.uk/ gerard/Managemen t/art1.html>.

[2] "Features - Law Librarians and their Evolving Role as Information Technology Managers LLRX.com." LLRX.com | Legal and Technology Articles and Resources for Librarians, Lawyers and Law Firms. Web. 05 May 009.http://www.llrx.com/features/evolving.htm>.

[3] Gordon, Moran, "Ethics, strengths and values: a review article", Journal of Librarianship and Information Science, 33, no. 2 (2001): 98-101. Print.

[4] Gordon-Till, Jonathan, "Ethics: the professional challenge", Business Information Review, 19, (2002): 46-54. Print.

[5] Hannabuss, Stuart, "Book Review: Librarianship and Human Rights: a TwentyFirst Century Guide by Toni Samek 2007, Oxford: Chandos Publishing”, Journal of Librarianship and Information Science, 40, no.1 (2008): 59-60. Print.

[6] "Managerial skills/competencies." Get Satisfaction People-Powered Customer Service. Web. 10 May 2009. <http://getsatisfaction.com/smutel/topics/mana gerial_skills_competencies $>$.

[7] Muirhead, Graeme A., "The role of the systems librarian in libraries in the United Kingdom", Journal of Librarianship and Information Science, 25, no.3, (1993): 123135. Print.

[8] NJLA: New Jersey Library Association. Web. 01 May 2009. <http://www.njla.org/resources/competencies. html>.

[9] O'Connor, M.J., "Review article: The librarian as manager", Journal of librarianship and information, 13 no.2, (1981): 131-135.

[10] Deshpande,Jayant., "ICT Applications to Library Sector", International Journal of esearch (IJR) Vol-1, Issue-9, October 2014 ISSN 2348-6848 :666-669. 